Document downloaded from:

http://hdl.handle.net/10251/50138

This paper must be cited as:

Moreno González, M.; Blasco Lanzuela, T.; Góra-Marek, K.; Palomares Gimeno, AE.; Corma Canós, A. (2014). Study of propane oxidation on Cu-zeolite catalysts by in-situ EPR and IR spectroscopies. Catalysis Today. 227:123-129. doi:10.1016/j.cattod.2013.10.055.

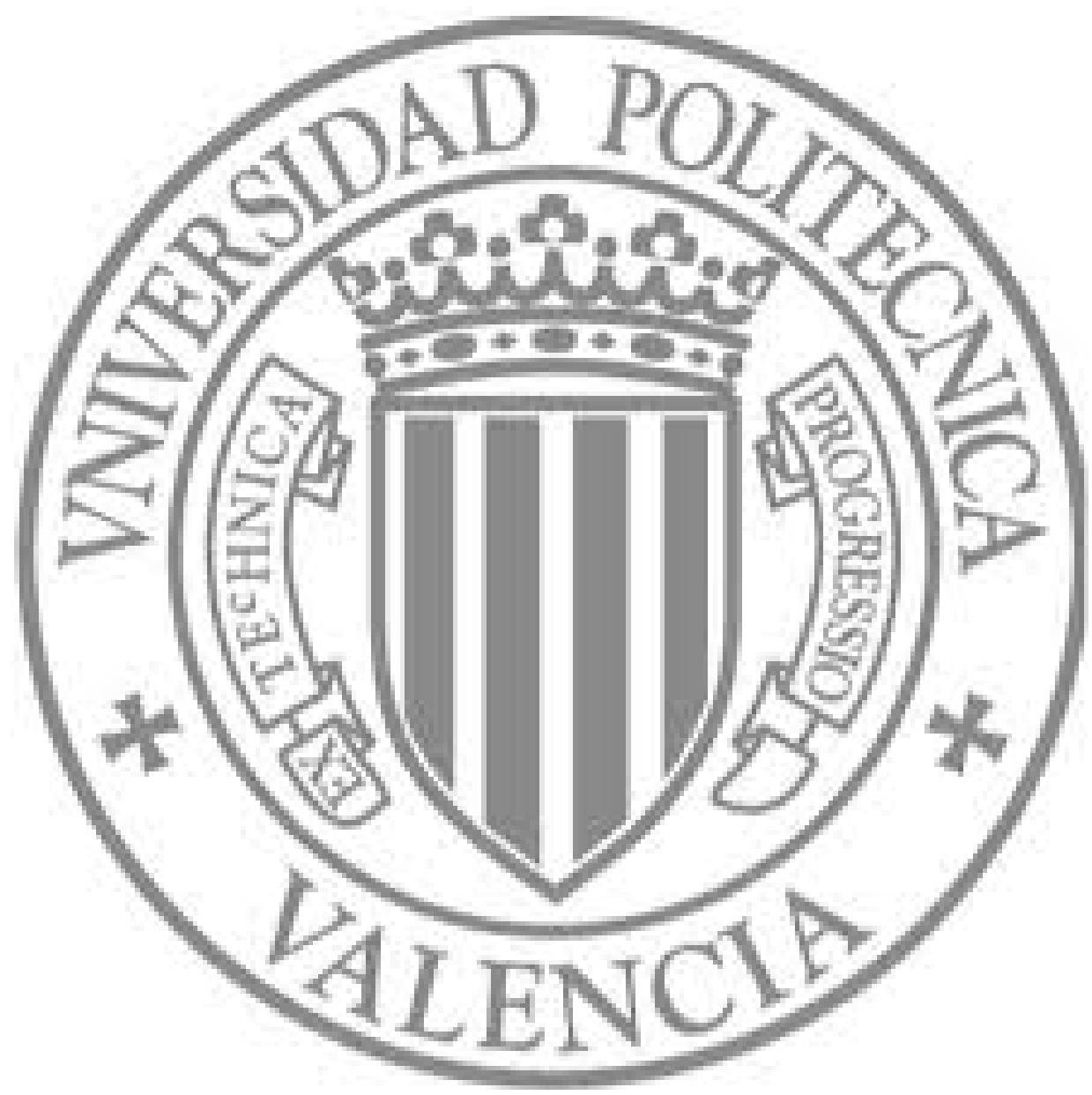

The final publication is available at

http://dx.doi.org/10.1016/j.cattod.2013.10.055

Copyright Elsevier 


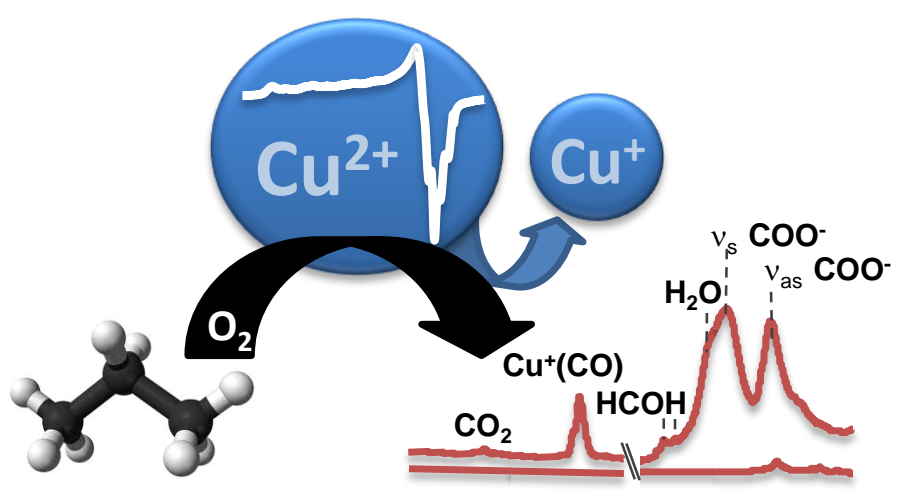




\title{
STUDY OF PROPANE OXIDATION ON CU-ZEOLITE CATALYSTS BY IN- SITU EPR AND IR SPECTROSCOPIES
}

\author{
M. Moreno González, ${ }^{1}$ T.Blasco, ${ }^{1 *}$ K. Góra-Marek, ${ }^{2}$ A.E. Palomares, ${ }^{1}$ A. Corma ${ }^{1}$ \\ ${ }^{1}$ Instituto de Tecnología Química (UPV-CSIC), Universidad Politécnica de Valencia- \\ Consejo Superior de Investigaciones Científicas, Avda. de los Naranjos s/n, 46022 \\ Valencia (Spain)
}

${ }^{2}$ Faculty of Chemistry, Jagiellonian University, Ingardena 3, 30-060 Krakow (Poland)

*Corresponding author E-mail: tblasco@itq.upv.es 


\begin{abstract}
Three $\mathrm{Cu}$-zeolites with different structure, $\mathrm{Cu}-\mathrm{TNU}-9, \mathrm{Cu}-\mathrm{ITQ}-2$ and $\mathrm{Cu}-\mathrm{Y}$ have been tested as catalysts for propane oxidation reaction and the activity follows the trend: $\mathrm{Cu}$ TNU-9 > Cu-ITQ-2 > Cu-Y, and in situ Electron Paramagnetic Resonance (EPR) and IR spectroscopies have been used to ascertain the origin of their different behavior. The IR spectra show bands ascribed to the formation of adsorbed $\mathrm{COO}^{-}$and $-\mathrm{CHO}$ as reaction intermediates in the oxidation of propane. The intensity of these bands for the $\mathrm{Cu}$-zeolites show the same tendency that their oxidation activity. The EPR spectra of the three $\mathrm{Cu}$-zeolites show that about $40-50 \%$ of total copper is present as isolated $\mathrm{Cu}^{2+}$ species, and heating under propane or propane-oxygen mixture at $350{ }^{\circ} \mathrm{C}$ provokes the reduction of $\mathrm{Cu}^{2+}$ to $\mathrm{Cu}^{+}$following the same trend that the oxidation activity, i.e., $\mathrm{Cu}$ TNU-9 > Cu-ITQ-2 > Cu-Y. Further analysis of the EPR spectra suggests that the reducibility of exchanged $\mathrm{Cu}^{2+}$ cations in the $\mathrm{Cu}$-zeolites is determined by their accessibility to the propane molecules.
\end{abstract}

\title{
Keywords
}

EPR

IR

Cu-Zeolite

Propane oxidation

SCR-NOx 


\section{Introduction}

Propane is the most abundant light hydrocarbon among the organic compounds emitted from combustion of liquefied petroleum gas (LPG), used in internal combustion engines in vehicles and in stationary applications. LPG is a common fuel because it has the advantage of giving clean combustion with no soot and few sulphur emissions and of simple storage. However, the exhaust gas from LPG combustor still contains a significant amount of hydrocarbons which are hazardous to the environment [1]. In order to fulfil the demanding environmental legislations, catalytic oxidation is a promising technology for controlling organic pollutant emissions such as propane [2].

Typical catalysts for total oxidation of hydrocarbons consist of supported noble metal $(\mathrm{Pt}, \mathrm{Pd}, \mathrm{Rh}, \mathrm{Au}$...) [2-6]. Alternatively, bulk metal oxides [7], mixed oxides (perovskites or hydrotalcites) $[1,8]$ or transition metal ion exchanged zeolites (TMIzeolites) have been explored as catalysts, and among them, those based on copper oxide give excellent activity in combustion of volatile organic compounds (VOCs) [9-14]. Moreover, $\mathrm{Cu}$-zeolites have been investigated in the last years because they exhibit high activity for NO decomposition and for NO selective catalytic reduction (NO-SCR) [1520]. This pollutant is produced in different combustion processes such as those taking place in diesel engines, and in this case, hydrocarbons, such as propane, have been suggested to be used as a reducing agents in the NO-SCR reaction. As Cu-zeolites can catalyse both reactions, there is an intense activity on the investigation of $\mathrm{Cu}$-exchanged zeolites aimed to elucidate the nature of copper active sites, their physical chemical properties and the reaction pathways.

In this work we have investigated the reaction of propane with oxygen with the aim of getting information on the mechanism of hydrocarbon oxidation on $\mathrm{Cu}$-zeolites, but also as a preliminary study to understand how $\mathrm{Cu}$-Zeolites catalyse the selective reduction of 
NO with propane in the presence of oxygen (HC-SCR-NO). For this purpose, we have chosen three zeolites with different topologies, $\mathrm{Cu}-\mathrm{Y}, \mathrm{Cu}-\mathrm{ITQ}-2$ and $\mathrm{Cu}-\mathrm{TNU}-9$, as catalysts. Zeolite Y possesses FAU-type structure consisting of a three dimentional system of 12 membered rings (12 MR) channels and supercages with diameter of about 11,2 A. ITQ-2 is the delaminated precursor of zeolite MCM-22 (MWW-type), being formed by single layers with external 12 MR cups and 10 MR channel system running in between the cups, inside the sheets. TNU-9 is a new zeolite with a structure consisting of a three dimensional channel system with pore openings of 10 MR. Here, we have employed EPR spectroscopy to study the redox properties of copper sites and follow their evolution upon heating in the presence of propane and propane-oxygen mixtures, and infrared spectroscopy to identify the intermediate species formed in the reaction of propane and oxygen. It will be shown that the ability of $\mathrm{Cu}$-zeolites for propane oxidation depends on the redox properties of the copper sites.

\section{Experimental}

Zeolite TNU-9 was synthesized according to the procedure described previously [21, 22], using 1,4-bis-(N-methylpryrrolidinium)-butane and $\mathrm{Na}^{+}$cations as structure directing agents (SDAs). ITQ-2 was prepared by swelling the MCM-22 precursor with a water solution of hexadecyltrimethylammonium bromide and tetrapropylammonium hydroxide following the method depicted in previous publications [23, 24]. Zeolite $\mathrm{Y}$ is commercially available (CBV 720, Zeolyst International). Prior to ion exchange, all zeolites were rinsed with a $0,04 \mathrm{M}$ solution of $\mathrm{NaNO}_{3}$ in order to have the materials in the sodium form. The metal exchange was carried out by immersing the zeolite in an aqueous solution of the desired amount of $\mathrm{Cu}\left(\mathrm{CH}_{3} \mathrm{COO}\right)_{2} \cdot 4 \mathrm{H}_{2} \mathrm{O}$, with a zeolite/liquid 
ratio of $10 \mathrm{~g} / \mathrm{l}$ and under stirring for $24 \mathrm{~h}$ at room temperature. The chemical composition of the samples was analyzed by ICP-O ES (Varian 715-ES), and the results are reported in Table 1.

EPR spectra were recorded with a Bruker EMX-12 spectrometer operating at the Xband, with a modulation frequency of $100 \mathrm{KHz}$ and amplitude of 1.0 Gauss. All spectra were measured at $-168{ }^{\circ} \mathrm{C}$ and quantitative analysis was carried out by double integration of the spectra, using $\mathrm{CuSO}_{4}$ as an external standard. About $20 \mathrm{mg}$ of the $\mathrm{Cu}$ zeolite sample was placed into $5 \mathrm{~mm}$ quartz EPR tubes adapted to a high vacuum valve and dehydrated under dynamic vacuum at $500{ }^{\circ} \mathrm{C}$ for $1 \mathrm{~h}$ reaching a final pressure $\approx 10^{-6}$ mbar. Propane and/or oxygen were then adsorbed at $-196{ }^{\circ} \mathrm{C}$ by connecting the sample tube on a vacuum line and admitting onto the $\mathrm{Cu}$-zeolite the desired amount of gas using a calibrated volume. In all experiments 2 molecules propane per atom of $\mathrm{Cu}$ were adsorbed. In another set of experiments, an excess of oxygen, about nine molecules of oxygen per atom of $\mathrm{Cu}$, was admitted into the sample tube immersed into liquid nitrogen after the adsorption of propane.

IR spectra were recorded with a Bruker Tensor 27 spectrometer (equipped with a MCT detector) with a spectral resolution of $2 \mathrm{~cm}^{-1}$. Thin wafers of Cu-zeolite $\left(5-10 \mathrm{mg} / \mathrm{cm}^{2}\right)$ were activated in the IR cell under vacuum at $500{ }^{\circ} \mathrm{C}$ for $1 \mathrm{~h}$, and then the adsorption of propane and/or oxygen was carried out at room temperature. Carbon monoxide (PRAXAIR 9.5) was used as a probe molecule.

Catalytic tests were carried out in a fixed bed, quartz tubular reactor. In the $\mathrm{C}_{3} \mathrm{H}_{8}$ oxidation experiments, $66.7 \mathrm{mg}$ of catalyst, as particles of $0.25-0.42 \mathrm{~mm}$ size, were introduced in the reactor, heated up to $500{ }^{\circ} \mathrm{C}$ under nitrogen flow and kept at this temperature for 30 minutes. After that, the desired temperature was set and the flow changed to the reaction feed consisting of $500 \mathrm{ml}^{\mathrm{min}}{ }^{-1}$ of a mixture composed by 
$0.33 \% \mathrm{C}_{3} \mathrm{H}_{8}, 6.9 \% \mathrm{O}_{2}$ and $\mathrm{N}_{2}$ as gas balance. The reaction was followed by the $\mathrm{CO}_{2}$ formed that was analysed with a non-dispersive infrared detector Servomex 4900.

\section{Results and discussion}

Table 1 shows the chemical composition and the level of copper exchange of the $\mathrm{Cu}-\mathrm{TNU}-9, \mathrm{Cu}-\mathrm{Y}$ and $\mathrm{Cu}-\mathrm{ITQ}-2$ zeolites used in this work, as well as the conversion of propane to $\mathrm{CO}_{2}$ in the oxidation reaction at $350^{\circ} \mathrm{C}$. This temperature is within the range typical for total oxidation and for SCR-NO reactions. As it can be observed in Table 1, the three $\mathrm{Cu}$-zeolites display a very different conversion being the highest for $\mathrm{Cu}-\mathrm{TNU}$ 9 and the lowest for $\mathrm{Cu}-\mathrm{Y}$, with an intermediate value for $\mathrm{Cu}-\mathrm{ITQ}-2$. In order to rationalize the different catalytic activity of these $\mathrm{Cu}$-zeolites we have combined EPR and infrared spectroscopy. The EPR and infrared spectra of Cu-zeolites were acquired after gas adsorption, and then after subsequent heating in an external oven at $350{ }^{\circ} \mathrm{C}$.

\section{EPR Spectroscopy}

EPR spectroscopy allows the detection of paramagnetic $\mathrm{Cu}^{2+}$ cations with a $\mathrm{d}^{9}$ electronic configuration, although only isolated $\mathrm{Cu}^{2+}$ are observed because the dipolar coupling among paramagnetic cations in aggregated species inhibit the observation of any EPR signal. The interaction of the magnetic moments associated with the unpaired electron of $\mathrm{Cu}^{2+}$ with the nuclear spin $\mathrm{I}=3 / 2$ of the two copper isotopes, ${ }^{63} \mathrm{Cu}$ and ${ }^{65} \mathrm{Cu}$ with natural abundance $69.15 \%$ and $30.85 \%$, respectively, gives rise to a hyperfine structure consisting of four lines. The EPR signals of $\mathrm{Cu}^{2+}$ in $\mathrm{Cu}$-zeolites are usually axially symmetric and the hyperfine structure is better resolved in the low field region of the spectra, corresponding to the parallel component. 
The EPR spectra of the Cu-zeolites studied here under ambient conditions (not shown) consist of an axially symmetric signal of octahedral $\mathrm{Cu}^{2+}$ resulting from the coordination to six $\mathrm{H}_{2} \mathrm{O}$ molecules, or more probable to $\mathrm{H}_{2} \mathrm{O}$ and oxygen atoms of the zeolite framework $\left[\mathrm{CuO}_{\mathrm{x}}\left(\mathrm{H}_{2} \mathrm{O}\right)_{6-\mathrm{x}}\right]^{2+}$ [25-33]. According to the quantification of the paramagnetic signals, isolated $\mathrm{Cu}^{2+}$ species accounts for $40-50 \%$ of total in the three $\mathrm{Cu}$-zeolites, indicating that about half of copper is EPR silent and must be in the form of small $\mathrm{CuO}$ particles not detected by $\mathrm{X}$-ray diffraction, or of $\mathrm{Cu}^{2+}-\mathrm{O}-\mathrm{Cu}^{2+}$ dimmers [3436]. Prior to gas adsorption, samples were degassed at $500{ }^{\circ} \mathrm{C}$ under high vacuum, which produced a strong decreases in the $\mathrm{Cu}^{2+}$ detected by EPR, to around $10 \%$ of total, indicating that most $\mathrm{Cu}^{2+}$ has been reduced to diamagnetic $\mathrm{Cu}^{+}$. These data are shown in Figure 1, which represent the amount of $\mathrm{Cu}^{2+}$ respect total copper content detected in the EPR spectra of Figures 2-4 recorded after submitting zeolites Cu-TNU9, $\mathrm{Cu}-\mathrm{Y}$ and $\mathrm{Cu}-\mathrm{ITQ}-2$ to different treatments. The parallel region of the spectra is magnified on the right part of Figures 2-4.

Figure 2a shows the EPR spectrum of zeolite $\mathrm{Cu}-\mathrm{TNU}-9$ evacuated at $500{ }^{\circ} \mathrm{C}$, which is formed by the superimposition of two axially symmetric signals, A and B, of isolated $\mathrm{Cu}^{2+}$. The $\mathrm{g}_{\perp}$, and $\mathrm{g}_{/ /}$and $\mathrm{A}_{/ /}$determined from the analysis of the expanded spectral region of Figure 2a right, are summarized in Table 2. To our knowledge, this is the first EPR study of zeolite Cu-TNU-9 and the assignment of signals of spectrum $2 \mathrm{~A}$ to specific copper sites requires deeper investigation, which is out of the scope of this manuscript. Nevertheless, from comparison of the parameters shown in Table 2 with those reported in the bibliography for other $\mathrm{Cu}^{2+}$ exchanged zeolites [37], signals $\mathrm{A}$ and $\mathrm{B}$ can be attributed to $\mathrm{Cu}^{2+}$ in square pyramidal and square planar configurations, respectively. Figure $2 \mathrm{~b}$ displays the spectrum recorded after the adsorption 2 molecules of $\mathrm{C}_{3} \mathrm{H}_{8}$ per $\mathrm{Cu}$ atom on $\mathrm{Cu}-\mathrm{TNU}-9$. Inspection of the low field region of the spectrum, 
Figure $2 \mathrm{~b}$ right, shows the appearance of a new signal $\mathrm{C}$ characterized by the parameters listed in Table 2, which must come from the interaction of $\mathrm{Cu}^{2+}$ with propane $\left(\mathrm{Cu}^{2+}-\right.$ $\mathrm{C}_{3} \mathrm{H}_{8}$ ). Although the spectrum of Figure $2 \mathrm{~b}$ is clearly dominated by signal $\mathrm{C}$, there may be some contribution of signal B and, in any case, it is difficult to rule out the presence of signals $\mathrm{A}$ and $\mathrm{B}$. After subsequent heating at $350{ }^{\circ} \mathrm{C}$, a sharp intensity decrease (see multiplication factor in the spectrum of Figure 2b) of the EPR spectrum is observed due to the reduction of $\mathrm{Cu}^{2+}$ to diamagnetic $\mathrm{Cu}^{+}$. Interestingly, only signal A remains in the spectrum, indicating that $\mathrm{Cu}^{2+}$ in square planar coordination (signal B) is more reducible, probably because its easier accessibility to propane molecules due to the lower coordination number. The spectrum recorded after the co-adsorption of propane and oxygen on zeolite $\mathrm{Cu}-\mathrm{TNU}-9$, shown in Figure 2d, is only slightly broader than that of Figure $2 \mathrm{~b}$, suggesting that the $\mathrm{Cu}^{2+}$ interacts preferably with propane. Subsequent heating at $350{ }^{\circ} \mathrm{C}$ the $\mathrm{Cu}$-TNU-9 zeolite with the mixture propane/oxygen decreases the intensity of the $\mathrm{Cu}^{2+}$ signals but to lesser extent than in the absence of oxygen (see Figures 1 and $2 \mathrm{~d}$ ), and provokes the disappearance of signals $\mathrm{A}$ and $\mathrm{B}$ and the appearance of a new signal $\mathrm{D}$ due to hydrated $\mathrm{Cu}^{2+}$ in octahedral coordination, and a second signal C', whose parameters are collected in Table 2. The $\mathrm{g}_{/ /}(2.372)$ and $\mathrm{A}_{/ /}$ (131 Gauss) values of signal D are smaller than those of the EPR signal of $\mathrm{Cu}^{2+}$ sites in the hydrated $\mathrm{Cu}-\mathrm{TNU}-9$ zeolite $\left(\mathrm{g}_{/ /}=2,383\right.$ and $\mathrm{A}_{/ /}=138$ Gauss), strongly suggesting that in the treated sample $\mathrm{Cu}^{2+}$ is coordinated to less water molecules and to more framework oxygen atoms of the zeolite $[25,38]$. The formation of this $\left[\mathrm{CuO}_{\mathrm{y}}\left(\mathrm{H}_{2} \mathrm{O}\right)_{6-\mathrm{y}}\right]^{2+}$ complex points out that water must have been produced upon heating, probably by oxidation of propane. The parameters of signal C', typical of $\mathrm{Cu}^{2+}$ in square pyramidal coordination, are very close to those of signal $\mathrm{C}$ (see Table 2) and then must be 
originated by the interaction of paramagnetic $\mathrm{Cu}^{2+}$ with and intermediate reaction product, in agreement with the results obtained by infrared spectroscopy (vide infra).

Figure 3 shows the EPR spectra of zeolite $\mathrm{Cu}-\mathrm{Y}$ submitted to treatments similar to zeolite $\mathrm{Cu}$-TNU-9. The spectrum of the sample degassed at $500{ }^{\circ} \mathrm{C}$, displayed in Figure $3 \mathrm{a}$, consists of two axially symmetric signals $\mathrm{E}$ and $\mathrm{F}$, characterized by the parameters listed in Table 3. Signals $\mathrm{E}$ and $\mathrm{F}$ have been previously assigned to $\mathrm{Cu}^{2+}$ located at two different exchange positions of the FAU type zeolite [29, 30, 39-42], or at sites containing different number of $\mathrm{Al}$ atoms in their close environment [43]. Assuming different location, signal $\mathrm{E}$ has been attributed to $\mathrm{Cu}^{2+}$ at the six member ring of SII site in the supercage $[40,41]$ or at SI' within the sodalite cage $[29,30]$, and signal F to $\mathrm{Cu}^{2+}$ at SI' $[40,41]$ or at SI sites inside the D6R [29, 30]. Adsorption of propane on zeolite $\mathrm{Cu}-\mathrm{Y}$ does not modifies the spectrum of the dehydrated zeolite (spectrum not shown), while subsequent heating at $350^{\circ} \mathrm{C}$ produces an intensity decrease (see Figure 3b) due to the reduction of $\mathrm{Cu}^{2+}$ to $\mathrm{Cu}^{+}$, although less than for zeolite Cu-TNU-9 (see Figure 1). The spectrum $3 \mathrm{~b}$ is dominated by signal $\mathrm{F}$, indicating that the species associated to signal $\mathrm{E}$ have been reduced probably because their easier accessibility to propane molecules. Then, signal $\mathrm{E}$ must be originated by $\mathrm{Cu}^{2+}$ species located at $\mathrm{SII}$ sites in the supercage, or alternatively inside the sodalite cages (site SI'), which move to accessible supercage positions upon heating. Figure $3 \mathrm{c}$ shows the spectrum recorded after co-adsorption of propane and oxygen on zeolite $\mathrm{Cu}-\mathrm{Y}$. The EPR signals of $\mathrm{Cu}^{2+}$ are broadened because of the dipolar interaction with paramagnetic oxygen molecules, making difficult the identification of the $\mathrm{Cu}^{2+}$ species. Comparison with the spectrum of Figure $2 \mathrm{~d}$ suggests a stronger interaction with oxygen than in zeolite Cu-TNU-9. Indeed, when $\mathrm{Cu}-\mathrm{Y}$ is heated at $350{ }^{\circ} \mathrm{C}$ with the propane-oxygen mixture, the overall intensity of the EPR spectrum (Figure 3d) increases indicating that, opposite to the 
results obtained for $\mathrm{Cu}$-TNU-9, copper has been oxidized. Despite the low resolution, analysis of the spectrum suggests the presence signals $\mathrm{E}$ and $\mathrm{F}$.

Figure 4 shows the EPR spectra of zeolite Cu-ITQ-2 evacuated at $500{ }^{\circ} \mathrm{C}$ (Fig. 4a), and heated at $350{ }^{\circ} \mathrm{C}$ with propane (Fig. 4b) or with propane/oxygen (Fig. 4c), and Table 4 collects the spectral parameters of the corresponding $\mathrm{Cu}^{2+}$ signals. The dehydrated $\mathrm{Cu}-\mathrm{ITQ}-2$ zeolite shows the presence of three axially symmetric $\mathrm{Cu}^{2+}$ signals, $\mathrm{G}, \mathrm{H}$ and $\mathrm{J}$. We have not found any publication reporting EPR results of $\mathrm{Cu}$ ITQ-2 zeolites. However, since ITQ-2 is obtained by de-lamination of the MCM-22 zeolite precursor, we have made a tentative attribution of the signals detected here by analogy to previous assignments made for Cu-MCM-22 [44-46]. Accordingly, signals G and $\mathrm{H}$ are attributed to $\mathrm{Cu}^{2+}$ species in square pyramidal coordination and signal $\mathrm{J}$ to $\mathrm{Cu}^{2+}$ in square planar symmetry. Propane adsorption produces only subtle modifications in the spectrum of the evacuated sample (not shown), and after subsequent heating, the intensity of the spectrum decreases and consists mainly of signal $\mathrm{H}$, indicating some reduction to $\mathrm{Cu}^{+}$, especially of species $\mathrm{J}$ and $\mathrm{G}$ (see Figure 4b). Heating zeolite $\mathrm{Cu}-\mathrm{ITQ}$ 2 under propane-oxygen produces the spectrum of Figure 4c, with intensity and shape similar to that of Figure 4a for the evacuated zeolite, but with the signals shifted. Indeed the spectrum consists of two new signals $\mathrm{K}$ and $\mathrm{L}$, characterized by the parameters listed in Table 4. Although the interpretation of spectrum 4c is not straight forward, signal $\mathrm{K}$ can be attributed to $\mathrm{Cu}^{2+}$ bonded to water molecules, based on the similarity of its parameters with those of signal D (Table 2). Meanwhile, the parameters of signal L are close to those of signal $\mathrm{H}$ and then can be tentatively attributed to $\mathrm{Cu}^{2+}$ in square pyramidal coordination in slightly different environment which may be due to the interaction with reaction intermediates. 
Comparison of the results shown in Figures 2-4 and the intensity of the $\mathrm{Cu}^{2+}$ EPR signals depicted in Figure 1 evidences different reducibility of $\mathrm{Cu}^{2+}$ in $\mathrm{Cu}-\mathrm{TNU}-9$, $\mathrm{Cu}-\mathrm{Y}$ and $\mathrm{Cu}-\mathrm{ITQ}-2$ zeolites when they are heated at $350{ }^{\circ} \mathrm{C}$ in the presence of propane and propane/oxygen. When propane is used, the EPR signals intensity decreases due to the reduction of $\mathrm{Cu}^{2+}$ to $\mathrm{Cu}^{+}$, and the amount of $\mathrm{Cu}^{2+}$ detected by EPR follows the trend: $\mathrm{Cu}-\mathrm{Y}>\mathrm{Cu}$-ITQ-2 $>\mathrm{Cu}$-TNU-9. The higher degree of copper reduction is attained in CuTNU-9, which takes place even in the presence of $\mathrm{O}_{2}$, whereas heating with propaneoxygen oxidizes $\mathrm{Cu}^{+}$to $\mathrm{Cu}^{2+}$ in zeolite $\mathrm{Cu}-\mathrm{Y}$. Meanwhile, an intermediate situation is observed for zeolite $\mathrm{Cu}-\mathrm{ITQ}-2$, as the intensity of isolated $\mathrm{Cu}^{2+}$ does not change significantly when the sample is heated at $350{ }^{\circ} \mathrm{C}$ with a mixture of propane-oxygen

\section{Infrared Spectroscopy}

Figure 5 shows the infrared spectra recorded at room temperature of zeolites $\mathrm{Cu}$ TNU-9, Cu-ITQ-2 and $\mathrm{Cu}-\mathrm{Y}$, after being heated at $350{ }^{\circ} \mathrm{C}$ for $30 \mathrm{~min}$ with a mixture propane/oxygen, and the spectra of propane adsorbed on these same zeolites for comparison purposes. After heating under propane-oxygen mixture, the spectrum recorded for zeolite $\mathrm{Cu}$-TNU-9 shows very intense bands in the $1650-1450 \mathrm{~cm}^{-1}$ frequency region, which are weaker for $\mathrm{Cu}-\mathrm{ITQ}-2$, and negligible for zeolite $\mathrm{Cu}-\mathrm{Y}$. The 1580 and $1480 \mathrm{~cm}^{-1}$ bands are characteristic of symmetric and antisymmetric stretching vibrations of the $\mathrm{COO}^{-}$group $\left(v_{\mathrm{s}} \mathrm{COO}^{-}\right.$and $\left.v_{\mathrm{as}} \mathrm{COO}^{-}\right)[47,48]$, and the small bands in the region 1750-1690 $\mathrm{cm}^{-1}$ can be originated from formaldehyde bonded to bridging hydroxyls groups $\left(1750 \mathrm{~cm}^{-1}\right)$ [47, 49] or interacting with $\mathrm{Cu}^{+}$sites $\left(1690 \mathrm{~cm}^{-1}\right)$ [50]. The presence of the absorption bands typical of $\mathrm{COO}^{-}$and $-\mathrm{CHO}$ groups points to a straightforward catalytic oxidation of the adsorbed propane by oxygen to acetates/formates or/and other oxygen containing compounds (formaldehyde). 
Oxidation of propane is also manifested by the appearance of new bands at $2346 \mathrm{~cm}^{-1}$, $2157 \mathrm{~cm}^{-1}$ and $1620 \mathrm{~cm}^{-1}$. The band at $2157 \mathrm{~cm}^{-1}$ is typical of $\mathrm{Cu}^{+}(\mathrm{CO})$ monocarbonyl $[51,52]$ formed by the interaction of $\mathrm{Cu}^{+}$with $\mathrm{CO}$ coming from the partial oxidation of propane, whereas the bands at $2346 \mathrm{~cm}^{-1}\left(\mathrm{CO}_{2}\right)$ and $1620 \mathrm{~cm}^{-1}\left(\mathrm{H}_{2} \mathrm{O}\right)$ confirms the total oxidation of propane. The band at $2137 \mathrm{~cm}^{-1}$ is assigned to $\mathrm{CO}$ bonded to $\mathrm{Cu}^{+}$cations coordinating water molecules, which are downshifted respect the $\mathrm{Cu}^{+}(\mathrm{CO})$ band (in the range $2157-2137 \mathrm{~cm}^{-1}$ ) because of the electron flow from the electron donor water molecule in $\left(\mathrm{H}_{2} \mathrm{O}\right) \mathrm{Cu}^{+}(\mathrm{CO})$ complexes [53]. The detection of hydrated copper species by IR agrees with the observation of hydrated $\left[\mathrm{CuO}_{y}\left(\mathrm{H}_{2} \mathrm{O}\right)_{6-y}\right]^{2+}$ complexes by EPR in zeolites $\mathrm{Cu}-\mathrm{TNU}-9$ and $\mathrm{Cu}-\mathrm{ITQ}-2$. Therefore the oxidation of propane in the presence of $\mathrm{O}_{2}$ produces $\mathrm{H}_{2} \mathrm{O}$ molecules which coordinate to both $\mathrm{Cu}^{+}$and $\mathrm{Cu}^{2+}$ cations. Since only $\mathrm{CO}_{2}$ has been observed as reaction product, the oxygenate species observed by infrared spectroscopy can be considered as intermediate products in the oxidation reaction.

Figure 6 shows the infrared spectra of the $\mathrm{Cu}$-zeolites submitted to the same treatment (heating with the propane/oxygen at $350{ }^{\circ} \mathrm{C}$ ) but recorded by cooling the IR cell down to $-20{ }^{\circ} \mathrm{C}$ to adsorb all reaction products. This experiment was carried out to check if the amount of final product, carbon dioxide, formed under the experimental conditions used for in situ IR agrees with the catalytic results reported in Table 1. The spectra of Figure 6 show that the intensity of the $\mathrm{CO}_{2}$ band at $2350 \mathrm{~cm}^{-1}$ is very weak for $\mathrm{Cu}-\mathrm{Y}$, while it is remarkable for zeolite $\mathrm{Cu}-\mathrm{TNU}-9$ and intermediate for $\mathrm{Cu}-\mathrm{ITQ}-2$. Consequently, the activity towards propane oxidation under these reaction conditions is in good agreement with the propane conversion obtained in the catalytic tests included in Table 1. Judging from the comparison of Figures 5 and 6 , the intensity of the acetate/formate $\left(1580\right.$ and $\left.1480 \mathrm{~cm}^{-1}\right)$ infrared bands are directly related with the $\mathrm{CO}_{2}$ 
production and then with the catalytic activity for the oxidation of propane of the $\mathrm{Cu}$ zeolites studied here. From the high intensity of acetate/formate bands we can conclude that the propane molecules are most effectively oxidized on $\mathrm{Cu}$-TNU-9 zeolite. Meanwhile the intensity of these bands is moderate for $\mathrm{Cu}-\mathrm{ITQ}-2$ and negligible for $\mathrm{Cu}$ Y zeolites in agreement with their intermediate and low activity for propane oxidation.

Figure 7 shows the IR spectra obtained after $\mathrm{CO}$ adsorption on $\mathrm{Cu}-\mathrm{TNU}-9$ evacuated at $500{ }^{\circ} \mathrm{C}$ and heated at $350{ }^{\circ} \mathrm{C}$ under propane (spectrum 7 a) or propane- $\mathrm{O}_{2}$ mixture (spectrum 7b). The spectrum 7a consists of only a band at $2157 \mathrm{~cm}^{-1}$ of $\mathrm{Cu}^{+}(\mathrm{CO})$ monocarbonyl species, while a weak IR band of $\mathrm{Cu}^{2+}(\mathrm{CO})$ at $2206 \mathrm{~cm}^{-1}$ is evident in the spectrum of Figure $7 \mathrm{~b}$ when also oxygen is present during heating. This result is in good agreement with the relative intensity of $\mathrm{Cu}^{2+}$ signals in the EPR spectra of the $\mathrm{Cu}$-TNU-9 zeolite heated with propane and with propane-oxygen (see Figure 1).

\section{General remarks}

Despite differences in experimental conditions imposed by the use of in situ cells appropriate for each spectroscopy, there is a good agreement in the main conclusions reached by IR and EPR spectroscopies and the catalytic tests. According to the results reported in Table 1, and the infrared spectra of Figure 6, the catalytic activity for the oxidation of propane with oxygen at $350^{\circ} \mathrm{C}$ follows the trend: $\mathrm{Cu}-\mathrm{TNU}-9>\mathrm{Cu}-\mathrm{ITQ}-2>$

$\mathrm{Cu}-\mathrm{Y}$. A similar trend is encountered for the reducibility of $\mathrm{Cu}^{2+}$ cations upon heating these $\mathrm{Cu}$-zeolites with propane or propane-oxygen. The highest oxidation activity of $\mathrm{Cu}$-TNU-9 is accompanied by the higher degree of reduction when heated under propane or propane-oxygen, as reflected by the decrease of the $\mathrm{Cu}^{2+} \mathrm{EPR}$ signal (see Figure 1). On the opposite, $\mathrm{Cu}-\mathrm{Y}$ show very low activity for propane oxidation and the 
intensity of the $\mathrm{Cu}^{2+}$ EPR signal decreases slightly when heated under propane, and even increase when heating upon propane-oxygen.

The different activity of zeolites $\mathrm{Cu}-\mathrm{TNU}-9, \mathrm{Cu}-\mathrm{ITQ}-2$ and $\mathrm{Cu}-\mathrm{Y}$ for propane oxidation (see table 1) cannot be explained by differences in the $\mathrm{Cu}$ content or the degree of aggregation of $\mathrm{Cu}^{2+}$, but as mentioned above, there is a correlation with the extent of reduction of the isolated $\mathrm{Cu}^{2+}$. Analysis of the EPR spectra strongly suggests that the reducibility of copper cations mostly depends on their accessibility to the propane molecules, and then on the distribution of $\mathrm{Cu}^{2+}$ in the zeolite. Accordingly, the EPR signals of $\mathrm{Cu}^{2+}$ in zeolite $\mathrm{Cu}-\mathrm{TNU}-9$, the most active for propane oxidation, are strongly modified by the adsorption of propane, whereas no changes are observe in the EPR spectrum of $\mathrm{Cu}-\mathrm{Y}$. Indeed, the EPR results indicate that $\mathrm{Cu}^{2+}$ in $\mathrm{Cu}-\mathrm{Y}$ is located inside the small cages (sodalite and/or hexagonal prisms) or in non-accessible position near the 6MR between the sodalite and supercage. Nevertheless, the intensity of the EPR signal of $\mathrm{Cu}^{2+}$ decreases when $\mathrm{CuY}$ is heated under propane, probably because thermal treatment favors migration of copper to accessible position producing some reduction of $\mathrm{Cu}^{2+}$ ions.

Finally, we must note that although the correlation between the catalyst activity and the copper reducibility suggest that isolated $\mathrm{Cu}^{2+}$ are active sites for propane oxidation, we cannot discard the contribution of aggregated copper species $(\mathrm{CuO}$ or $\mathrm{Cu}-\mathrm{O}-\mathrm{Cu}$ dimmers) as active sites for the reaction.

To summarize, the results reported here suggest that the catalytic activity for propane oxidation to $\mathrm{CO}_{2}$, which follows the trend $\mathrm{Cu}-\mathrm{TNU}-9>\mathrm{Cu}-\mathrm{ITQ}-2>\mathrm{Cu}-\mathrm{Y}$, depends on the reducibility of $\mathrm{Cu}^{2+}$ cations at exchange position, which is determined by its accessibility to propane molecules. Meanwhile, in situ IR spectroscopy shows that adsorbed formate/aldehyde species are reaction intermediates formed during oxidation. 


\section{Acknowledgements}

The authors acknowledge the financial support from the Spanish Ministry of Economy and Competitiveness through the Severo Ochoa program (SEV-2012-0267) as well as operating grants Consolider Ingenio Multicat (CSD-2009-00050) and MAT-2012-3856C02-01.

\section{References}

[1] Z. Jiang, L. Kong, Z. Chu, L.J. France, T. Xiao and P.P. Edwards, Fuel, 96 (2012) 257.

[2] M.N. Taylor, W. Zhou, T. Garcia, B. Solsona, A.F. Carley, C.J. Kiely and S.H. Taylor, Journal of Catalysis, 285 (2012) 103.

[3] O.R. Inderwildi and S.J. Jenkins, Chemical Society Reviews, 37 (2008) 2274.

[4] S. Scirè and L.F. Liotta, Applied Catalysis B: Environmental, 125 (2012) 222.

[5] X. Wu, L. Zhang, D. Weng, S. Liu, Z. Si and J. Fan, Journal of Hazardous Materials, 225-226 (2012) 146.

[6] Z. Zhu, G. Lu, Y. Guo, Y. Guo, Z. Zhang, Y. Wang and X.-Q. Gong, ChemCatChem, (2013) n/a.

[7] B. Solsona, T. Garcia, S. Agouram, G.J. Hutchings and S.H. Taylor, Applied Catalysis B: Environmental, 101 (2011) 388.

[8] N.A. Merino, B.P. Barbero, P. Grange and L.E. Cadús, Journal of Catalysis, 231 (2005) 232.

[9] R. Bulánek, B. Wichterlová, Z. Sobalík and J. Tichý, Applied Catalysis B: Environmental, 31 (2001) 13.

[10] Z. Chajar, M. Primet and H. Praliaud, Journal of Catalysis, 180 (1998) 279.

[11] A.K. Neyestanaki, N. Kumar and L.-E. Lindfors, Fuel, 74 (1995) 690. 
[12] K. Alexopoulos, M. Anilkumar, M.-F. Reyniers, H. Poelman, S. Cristol, V.

Balcaen, P.M. Heynderickx, D. Poelman and G.B. Marin, Applied Catalysis B:

Environmental, 97 (2010) 381.

[13] V. Balcaen, H. Poelman, D. Poelman and G.B. Marin, Journal of Catalysis, 283 (2011) 75 .

[14] P.M. Heynderickx, J.W. Thybaut, H. Poelman, D. Poelman and G.B. Marin, Journal of Catalysis, 272 (2010) 109.

[15] M. Iwamoto, H. Yahiro, K. Tanda, N. Mizuno, Y. Mine and S. Kagawa, The Journal of Physical Chemistry, 95 (1991) 3727.

[16] Y. Traa, B. Burger and J. Weitkamp, Microporous and Mesoporous Materials, $30(1999) 3$.

[17] V.A. Sadykov, V.V. Lunin, V.A. Matyshak, E.A. Paukshtis, A.Y. Rozovskii, N.N. Bulgakov and J.R.H. Ross, Kinetics and Catalysis, 44 (2003) 379.

[18] S. Brandenberger, O. Kröcher, A. Tissler and R. Althoff, Catalysis Reviews, 50 (2008) 492.

[19] C. Franch-Martí, C. Alonso-Escobar, J.L. Jorda, I. Peral, J. HernándezFenollosa, A. Corma, A.E. Palomares, F. Rey and G. Guilera, Journal of Catalysis, 295 (2012) 22.

[20] U. Deka, I. Lezcano-Gonzalez, B.M. Weckhuysen and A.M. Beale, ACS Catalysis, 3 (2013) 413.

[21] S.B. Hong, E.G. Lear, P.A. Wright, W. Zhou, P.A. Cox, C.-H. Shin, J.-H. Park and I.-S. Nam, Journal of the American Chemical Society, 126 (2004) 5817.

[22] S.B. Hong, H.-K. Min, C.-H. Shin, P.A. Cox, S.J. Warrender and P.A. Wright, Journal of the American Chemical Society, 129 (2007) 10870. 
[23] A. Corma, V. Fornes, S.B. Pergher, T.L.M. Maesen and J.G. Buglass, Nature, 396 (1998) 353.

[24] A. Corma, V. Fornés, J.M. Guil, S. Pergher, T.L.M. Maesen and J.G. Buglass, Microporous and Mesoporous Materials, 38 (2000) 301.

[25] M.W. Anderson and L. Kevan, The Journal of Physical Chemistry, 91 (1987) 4174.

[26] S.C. Larsen, A. Aylor, A.T. Bell and J.A. Reimer, The Journal of Physical Chemistry, 98 (1994) 11533.

[27] S.-K. Park, V. Kurshev, Z. Luan, C. Wee Lee and L. Kevan, Microporous and Mesoporous Materials, 38 (2000) 255.

[28] J. Xu, J.-S. Yu, S.J. Lee, B.Y. Kim and L. Kevan, The Journal of Physical Chemistry B, 104 (2000) 1307.

[29] J.S. Yu and L. Kevan, The Journal of Physical Chemistry, 94 (1990) 7612.

[30] T. Ichikawa and L. Kevan, The Journal of Physical Chemistry, 87 (1983) 4433.

[31] H. Yahiro, Y. Ohmori and M. Shiotani, Microporous and Mesoporous Materials, 83 (2005) 165.

[32] J. Wang, T. Yu, X. Wang, G. Qi, J. Xue, M. Shen and W. Li, Applied Catalysis B: Environmental, 127 (2012) 137.

[33] M. Zamadics, X. Chen and L. Kevan, The Journal of Physical Chemistry, 96 (1992) 2652.

[34] F.X. Llabrés i Xamena, P. Fisicaro, G. Berlier, A. Zecchina, G.T. Palomino, C. Prestipino, S. Bordiga, E. Giamello and C. Lamberti, The Journal of Physical Chemistry B, 107 (2003) 7036.

[35] G.T. Palomino, P. Fisicaro, S. Bordiga, A. Zecchina, E. Giamello and C. Lamberti, The Journal of Physical Chemistry B, 104 (2000) 4064. 
[36] J.Y. Yan, G.D. Lei, W.M.H. Sachtler and H.H. Kung, Journal of Catalysis, 161 (1996) 43.

[37] A. Delabie, K. Pierloot, Marijke H. Groothaert, Robert A. Schoonheydt and Luc G. Vanquickenborne, European Journal of Inorganic Chemistry, 2002 (2002) 515.

[38] M. Zamadics, X. Chen and L. Kevan, The Journal of Physical Chemistry, 96 (1992) 5488.

[39] D. Berthomieu, J.-M. Ducéré and A. Goursot, The Journal of Physical Chemistry B, 106 (2002) 7483.

[40] R.A. Schoonheydt, Catalysis Reviews, 35 (1993) 129.

[41] J.C. Conesa and J. Soria, Journal of the Chemical Society, Faraday Transactions 1: Physical Chemistry in Condensed Phases, 75 (1979) 406.

[42] D. Berthomieu, J.M. Ducéré and A. Goursot, in G.G. R. Aiello and F. Testa (Editors), Studies in Surface Science and Catalysis, Vol. Volume 142, Elsevier, 2002, p. 1899.

[43] K. Pierloot, A. Delabie, M. Groothaert and R. Schoonheydt, Phys. Chem. Chem. Phys., 3 (2001) 2174.

[44] P. Kaminski, I. Sobczak, P. Decyk, M. Ziolek, W.J. Roth, B. Campo and M. Daturi, The Journal of Physical Chemistry C, 117 (2013) 2147.

[45] M. Milanesio, G. Croce, D. Viterbo, H.O. Pastore, A.J.d.S. Mascarenhas, E.C.d.O. Munsignatti and L. Meda, The Journal of Physical Chemistry A, 112 (2008) 8403.

[46] T. Wasowicz, A.M. Prakash and L. Kevan, Microporous Materials, 12 (1997) 107.

[47] E. Kukulska-Zając, K. Góra-Marek and J. Datka, Microporous and Mesoporous Materials, 96 (2006) 216. 
[48] M. Davies, Elsevier, Amsterdam/London/New York, (1963) 419.

[49] K. Góra-Marek, Microporous and Mesoporous Materials, 145 (2011) 93.

[50] E. Kukulska-Zając and J. Datka, The Journal of Physical Chemistry C, 111 (2007) 3471.

[51] G. Hubner, G. Rauhut, H. Stoll and E. Roduner, Physical Chemistry Chemical Physics, 4 (2002) 3112.

[52] G.T. Palomino, S. Bordiga, A. Zecchina, G.L. Marra and C. Lamberti, The Journal of Physical Chemistry B, 104 (2000) 8641.

[53] K. Góra-Marek, Vibrational Spectroscopy, 58 (2012) 104. 


\section{Figures Caption}

Figure 1: Intensity of EPR signals expressed as the percentage of $\mathrm{Cu}$ (II) detected by EPR respect to the copper content determined by chemical analysis, after the treatment indicated in the Figure.

Figure 2: EPR spectra at $-168{ }^{\circ} \mathrm{C}$ of $\mathrm{Cu}-\mathrm{TNU}-9$ catalyst evacuated at $500{ }^{\circ} \mathrm{C}$ (a) and then after propane adsorption (2 molecules of $\mathrm{C}_{3} \mathrm{H}_{8}$ per atom of $\mathrm{Cu}$ ) (b) and subsequent heating at $350{ }^{\circ} \mathrm{C}$ for 30 minutes (c); and after adsorption 2 molecules of $\mathrm{C}_{3} \mathrm{H}_{8}$ and 12 of $\mathrm{O}_{2}$ per atom of $\mathrm{Cu}(\mathrm{d})$ and subsequent heating at $350{ }^{\circ} \mathrm{C}$ for 30 minutes (e). On the right: magnification of the low-field hyperfine features of the normalized EPR spectra.

Figure 3: EPR spectra at $-168{ }^{\circ} \mathrm{C}$ of $\mathrm{Cu}-\mathrm{Y}$ catalyst evacuated at $500{ }^{\circ} \mathrm{C}$ (a) and then after propane adsorption ( 2 molecules of $\mathrm{C}_{3} \mathrm{H}_{8}$ per atom of $\mathrm{Cu}$ ) and heating at $350{ }^{\circ} \mathrm{C} 30$ min (b); after adsorption of 2 molecules of $\mathrm{C}_{3} \mathrm{H}_{8}$ and 15 of $\mathrm{O}_{2}$ per atom of $\mathrm{Cu}$ (c) and subsequently heating at $350{ }^{\circ} \mathrm{C} 30 \mathrm{~min}$ (d). On the right: magnification of the low-field hyperfine features of the normalized EPR spectra.

Figure 4: EPR spectra at $-168{ }^{\circ} \mathrm{C}$ of $\mathrm{Cu}-\mathrm{ITQ}-2$ catalyst evacuated at $500{ }^{\circ} \mathrm{C}$ (a) and then after propane adsorption ( 2 molecules of $\mathrm{C}_{3} \mathrm{H}_{8}$ per atom of $\mathrm{Cu}$ ) and heating at $350{ }^{\circ} \mathrm{C}$ for 30 minutes (b); and after adsorption of 2 molecules of $\mathrm{C}_{3} \mathrm{H}_{8}$ and 9 of $\mathrm{O}_{2}$ per atom of $\mathrm{Cu}$ and heating at $350{ }^{\circ} \mathrm{C}$ for 30 minutes (c). On the right: magnification of the low-field hyperfine features of the normalized EPR spectra.

Figure 5: IR spectra of Cu-TNU-9 (a), Cu-ITQ-2 (b) and Cu-Y (c) zeolites recorded after adsorption of propane $(\mathrm{a}, \mathrm{b}, \mathrm{c})$ and after heating at $350^{\circ} \mathrm{C}$ for 30 minutes in the presence of propane and oxygen $\left(a^{\prime}, b^{\prime}, c^{\prime}\right)$.

Figure 6. IR spectra of $\mathrm{CO}_{2}$ produced during heating with propane/oxygen mixture at $350{ }^{\circ} \mathrm{C}$. Spectrum was collected at $-20^{\circ} \mathrm{C}$. 
Figure 7. IR spectra of $\mathrm{CO}$ adsorbed on CuTNU-9 catalyst evacuated at $500{ }^{\circ} \mathrm{C}$ : after heating with propane at $350{ }^{\circ} \mathrm{C}$ (a) and after heating with propane/oxygen mixture at $350{ }^{\circ} \mathrm{C}(\mathrm{b})$. Carbon monoxide was sorbed at $-150{ }^{\circ} \mathrm{C}$. 


\section{Table 1}

Chemical composition of the Cu-zeolites used in this study and the propane conversion to $\mathrm{CO}_{2}$ in the oxidation reaction.

\begin{tabular}{|c|c|c|c|c|c|}
\hline Catalyst & wt \% Cu & $\mathrm{Si} / \mathrm{Al}$ & $\mathrm{Cu} / \mathrm{Al}$ & $\%$ Exchange & $\%$ Conversion \\
\hline $\mathrm{Cu}-\mathrm{Y}$ & 3,29 & 11 & 0,47 & 94 & 10 \\
\hline Cu-ITQ-2 & 2,74 & 20 & 0,62 & 123 & 40 \\
\hline Cu-TNU-9 & 4,16 & 14 & 0,67 & 135 & 85 \\
\hline
\end{tabular}




\section{Table 2}

EPR parameters of the $\mathrm{Cu}^{2+}$ signals of zeolite $\mathrm{Cu}$-TNU-9 submitted to different treatments corresponding to the spectra displayed in Figure 2.

\begin{tabular}{|c|c|c|c|c|c|}
\hline \multirow[b]{2}{*}{ Treatment } & \multirow[b]{2}{*}{ Signal } & \multicolumn{3}{|c|}{ EPR parameters } & \multirow[b]{2}{*}{$\mathrm{Cu}^{2+}$ species } \\
\hline & & $A_{\|} /$Gauss & $g_{\|}$ & $g_{\perp}$ & \\
\hline \multirow[t]{2}{*}{ Evac at $500^{\circ} \mathrm{C}$} & $A$ & 163 & 2,303 & 2,058 & $\mathrm{Cu}^{2+}$ sq-pyr \\
\hline & B & 171 & 2,282 & - & $\mathrm{Cu}^{2+}{ }_{\text {sq-pl }}$ \\
\hline $2 \mathrm{C}_{3} \mathrm{H}_{8} / \mathrm{Cu}$ & $\mathrm{C}$ & 155 & 2,318 & 2,048 & $\mathrm{Cu}^{2+}-\mathrm{C}_{3} \mathrm{H}_{8}$ \\
\hline $2 \mathrm{C}_{3} \mathrm{H}_{8} / \mathrm{Cu} \mathrm{T}_{\text {reac }}=350 \stackrel{\circ}{\mathrm{C}}$ & $A$ & 161 & 2,316 & 2,059 & $\mathrm{Cu}^{2+}{ }_{\text {sq-pyr }}$ \\
\hline \multirow[t]{2}{*}{$2 \mathrm{C}_{3} \mathrm{H}_{8} / 12 \mathrm{O}_{2} / \mathrm{Cu} \mathrm{T}_{\text {reac }}=350^{\circ} \mathrm{C}$} & $\mathrm{D}$ & 131 & 2,372 & 2,078 & $\mathrm{Cu}^{2+}-\mathrm{H}_{2} \mathrm{O}$ \\
\hline & $C^{\prime}$ & 156 & 2,325 & 2,048 & $\mathrm{Cu}^{2+}-\mathrm{C}_{\mathrm{x}} \mathrm{H}_{\mathrm{y}} \mathrm{O}_{z}$ \\
\hline
\end{tabular}




\section{Table 3}

EPR parameters of the $\mathrm{Cu}^{2+}$ signals of zeolite $\mathrm{Cu}-\mathrm{Y}$ submitted to different treatments, corresponding to the spectra displayed in Figure 3.

\begin{tabular}{|c|c|c|c|c|c|}
\hline \multirow[b]{2}{*}{ Treatment } & \multirow[b]{2}{*}{ Signal } & \multicolumn{3}{|c|}{ EPR parameters } & \multirow[b]{2}{*}{$\mathrm{Cu}^{2+}$ species } \\
\hline & & $A_{\|} /$Gauss & $g_{\|}$ & $g_{\perp}$ & \\
\hline \multirow[t]{2}{*}{ Evac at $500^{\circ} \mathrm{C}$} & $E$ & 127 & 2,380 & 2,060 & SII/SI' \\
\hline & $\mathrm{F}$ & 157 & 2,330 & - & Sl'/SI \\
\hline $2 \mathrm{C}_{3} \mathrm{H}_{8} / \mathrm{Cu} \mathrm{T}_{\text {reac }}=350^{\circ} \mathrm{C}$ & $\mathrm{F}$ & 157 & 2,330 & 2,059 & SI'/SI \\
\hline \multirow[t]{2}{*}{$2 \mathrm{C}_{3} \mathrm{H}_{8} / 15 \mathrm{O}_{2} / \mathrm{Cu} \mathrm{T}_{\text {reac }}=350 \stackrel{\circ}{\mathrm{C}}$} & $E$ & 127 & 2,380 & 2,060 & SII/SI' \\
\hline & $\mathrm{F}$ & 157 & 2,314 & - & SI'/SI \\
\hline
\end{tabular}




\section{Table 4}

EPR parameters of the $\mathrm{Cu}^{2+}$ signals of zeolite Cu-ITQ-2 submitted to different treatments, corresponding to the spectra displayed in Figure 4.

\begin{tabular}{|c|c|c|c|c|c|}
\hline \multirow[b]{2}{*}{ Treatment } & \multirow[b]{2}{*}{ Signal } & \multicolumn{3}{|c|}{ EPR parameters } & \multirow[b]{2}{*}{$\mathrm{Cu}^{2+}$ species } \\
\hline & & $A_{\|} /$Gauss & $g_{\|}$ & $g_{\perp}$ & \\
\hline \multirow[t]{3}{*}{ Evac at $500^{\circ} \mathrm{C}$} & G & 139 & 2,355 & 2,043 & $\mathrm{Cu}^{2+}{ }_{\text {sq-pyr }}$ \\
\hline & $\mathrm{H}$ & 161 & 2,333 & - & $\mathrm{Cu}^{2+}$ sq-pyr \\
\hline & $\mathrm{J}$ & 167 & 2,280 & - & $\mathrm{Cu}^{2+}$ sq-pl \\
\hline $2 \mathrm{C}_{3} \mathrm{H}_{8} / \mathrm{Cu} \mathrm{T}_{\text {reac }}=350 \stackrel{\circ}{\mathrm{C}}$ & $\mathrm{H}$ & 157 & 2,329 & 2,060 & $\mathrm{Cu}^{2+}$ sq-pyr \\
\hline \multirow[t]{2}{*}{$2 \mathrm{C}_{3} \mathrm{H}_{8} / 12 \mathrm{O}_{2} / \mathrm{Cu} \mathrm{T}_{\text {reac }}=350^{\circ} \mathrm{C}$} & $\mathrm{K}$ & 132 & 2,374 & 2,061 & $\mathrm{Cu}^{2+}-\mathrm{H}_{2} \mathrm{O}$ \\
\hline & $\mathrm{L}$ & 157 & 2,340 & - & $\mathrm{Cu}^{2+}-\mathrm{C}_{x} \mathrm{H}_{\mathrm{y}} \mathrm{O}_{z}$ \\
\hline
\end{tabular}




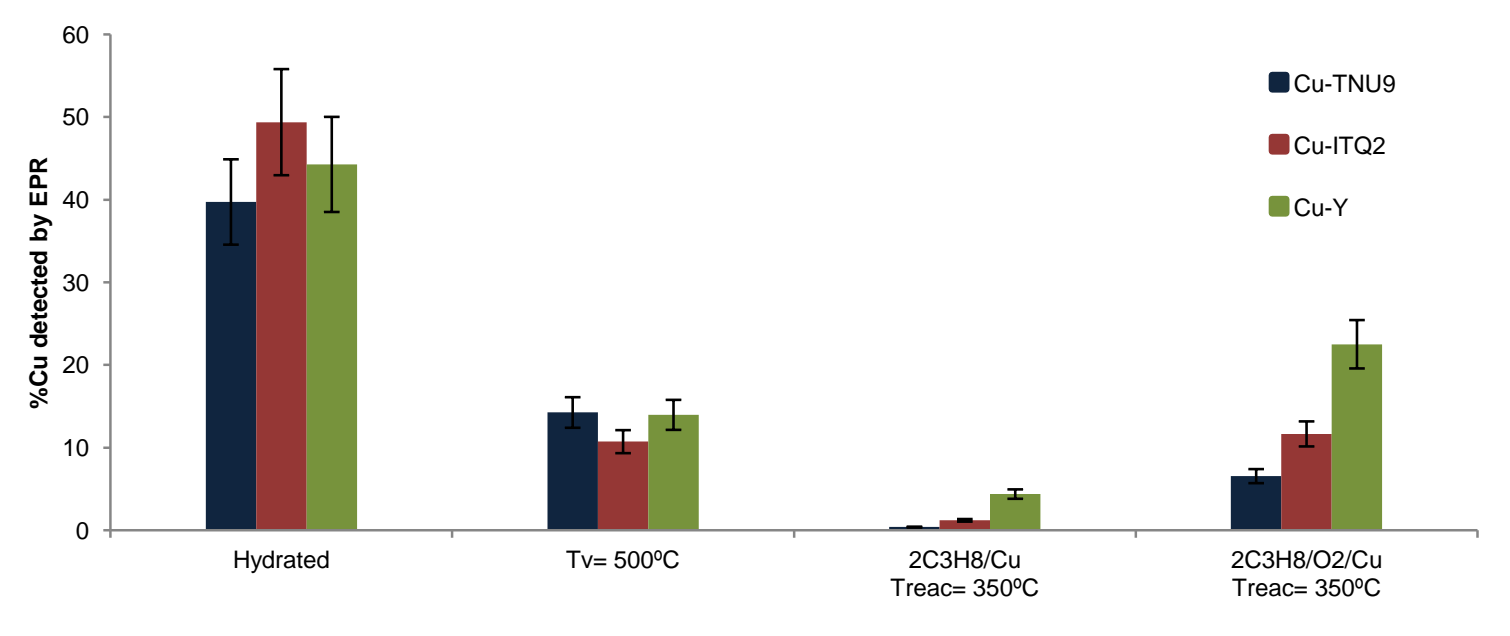

Figure 1

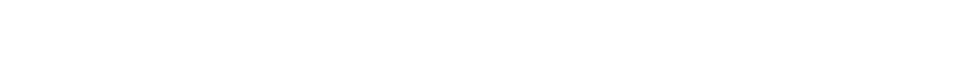
Figure 1 
Figure
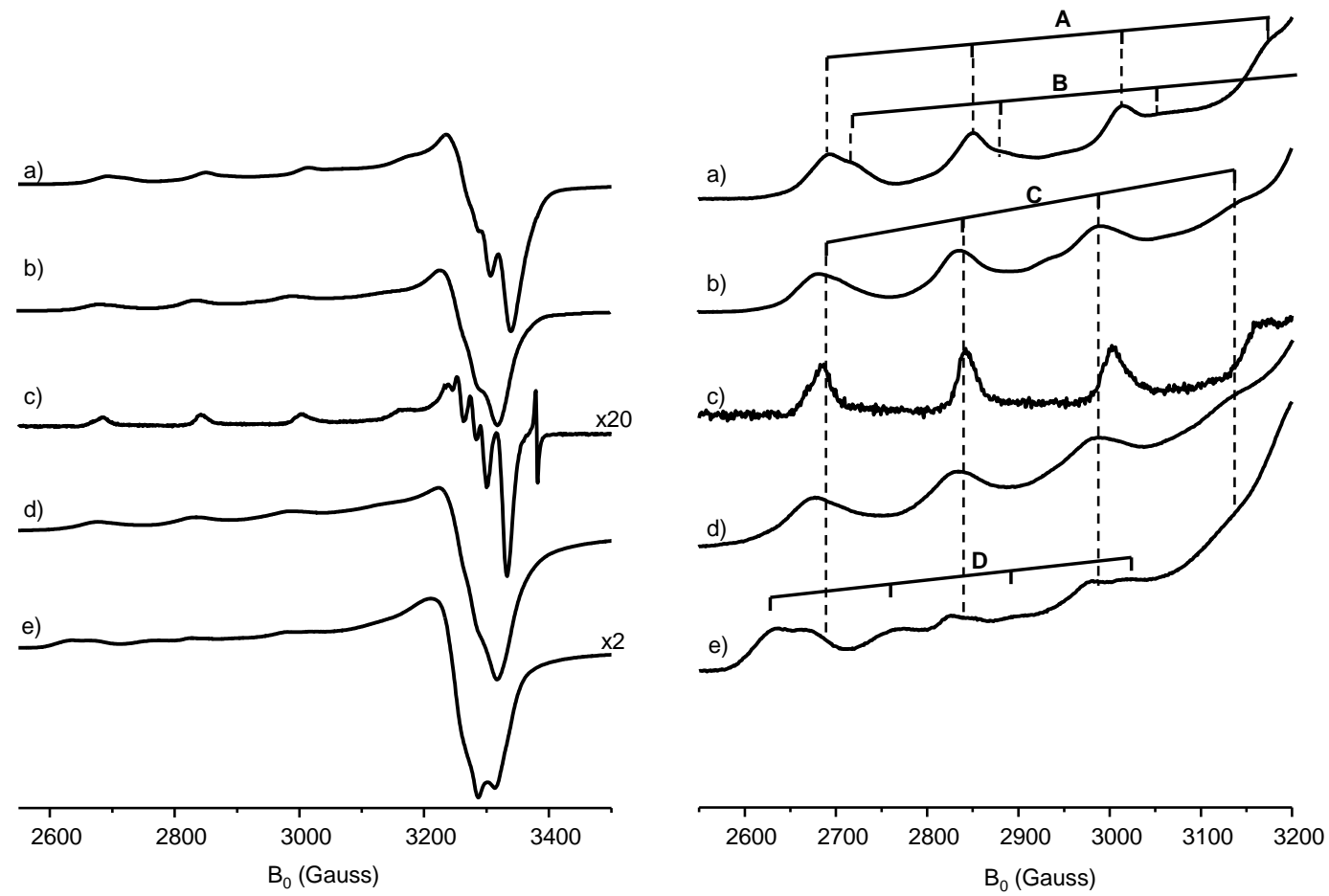

Figure 2 

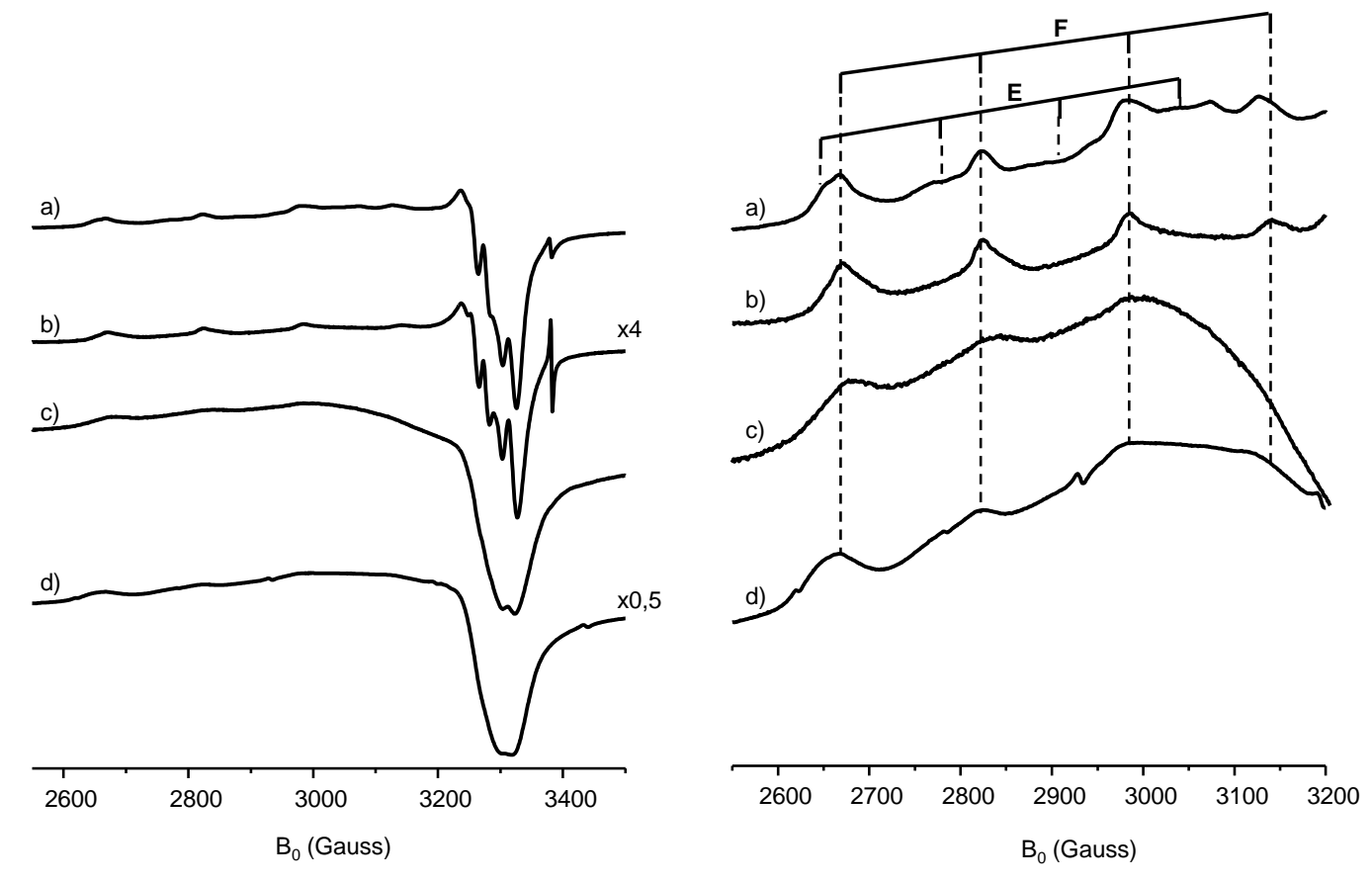

Figure 3 

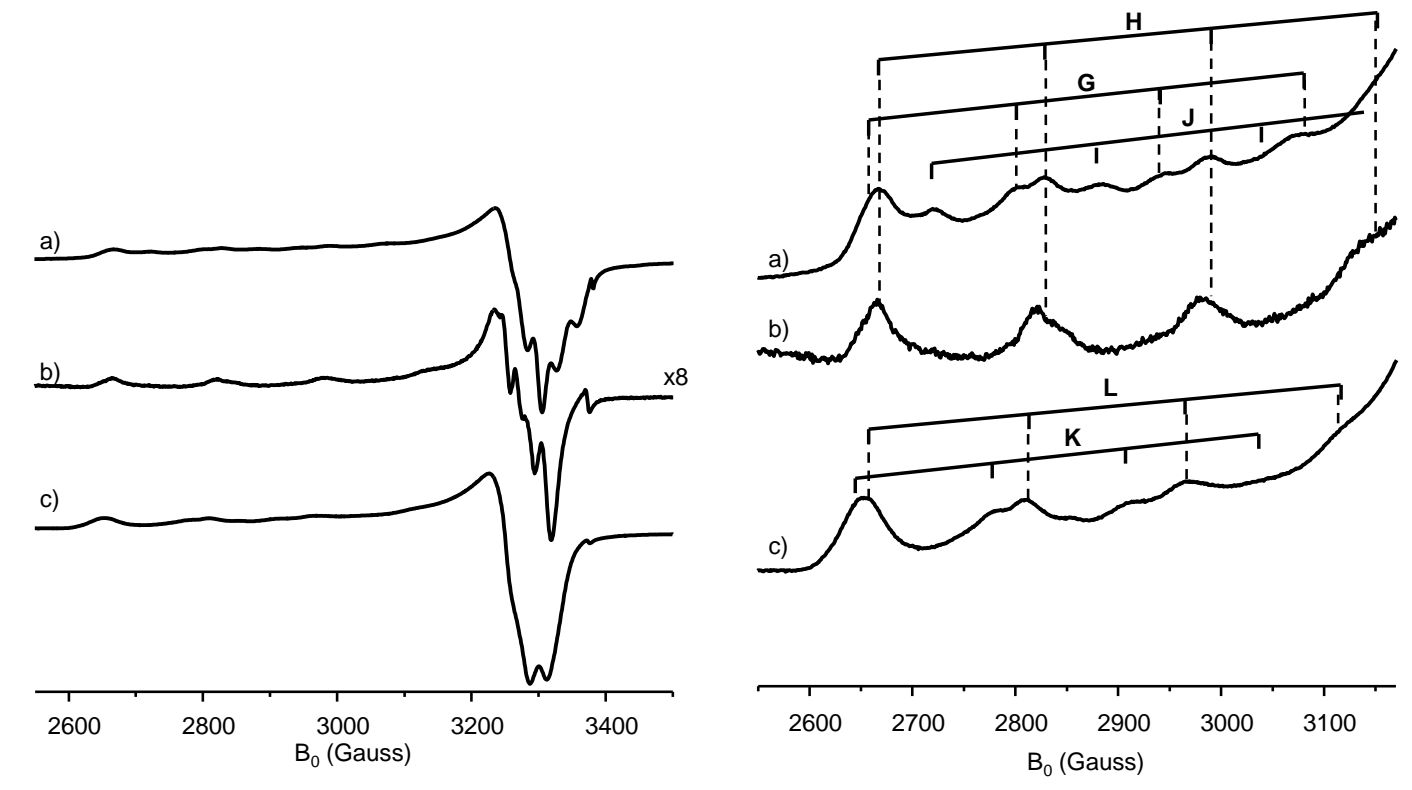

Figure 4 


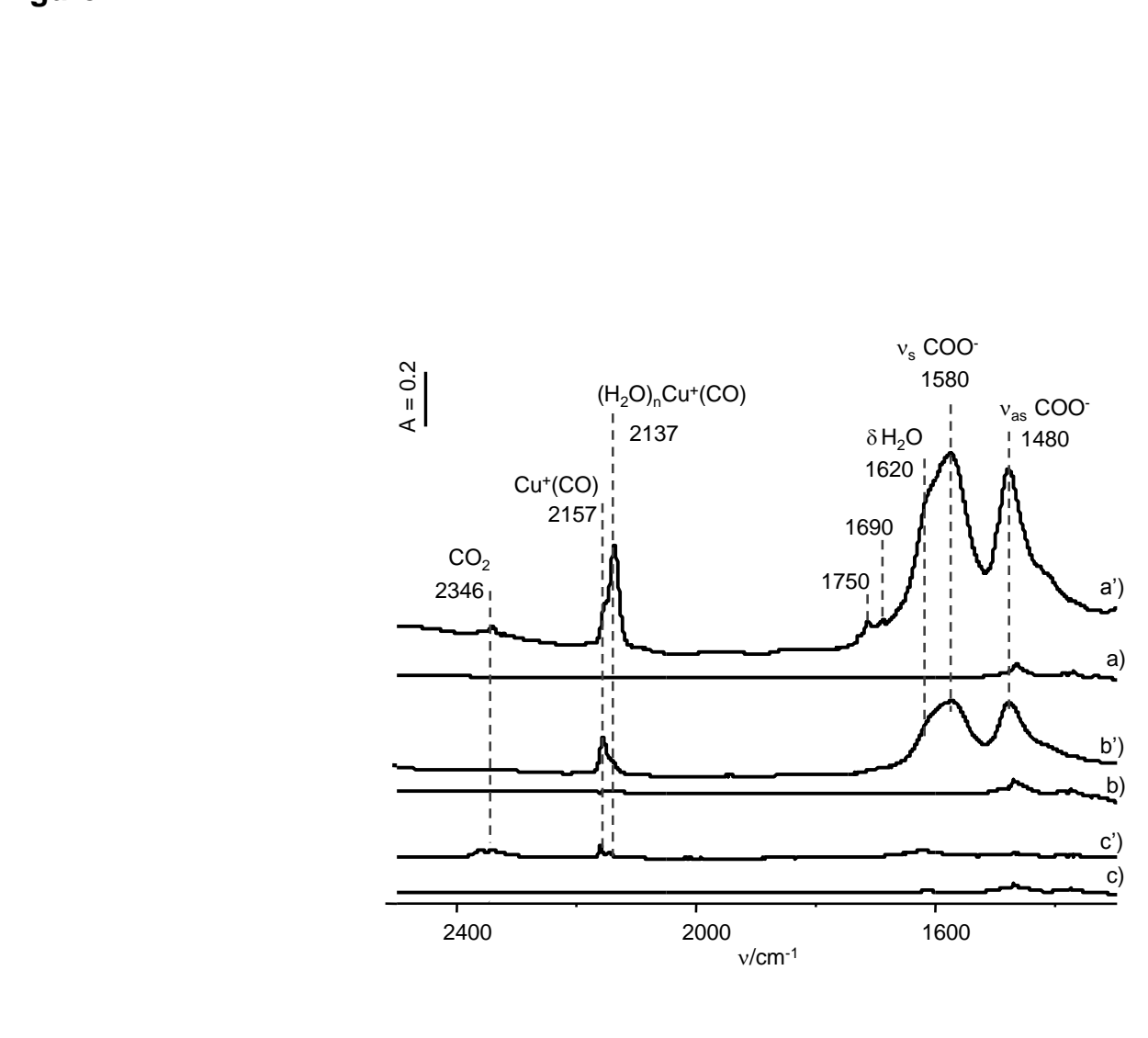

\section{Figure 5 \\ .}

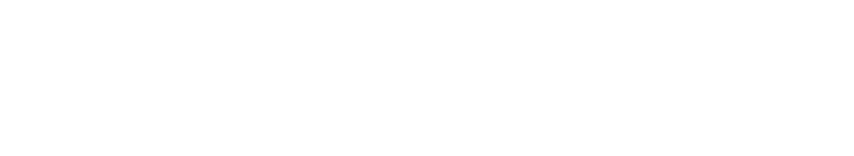

.

更
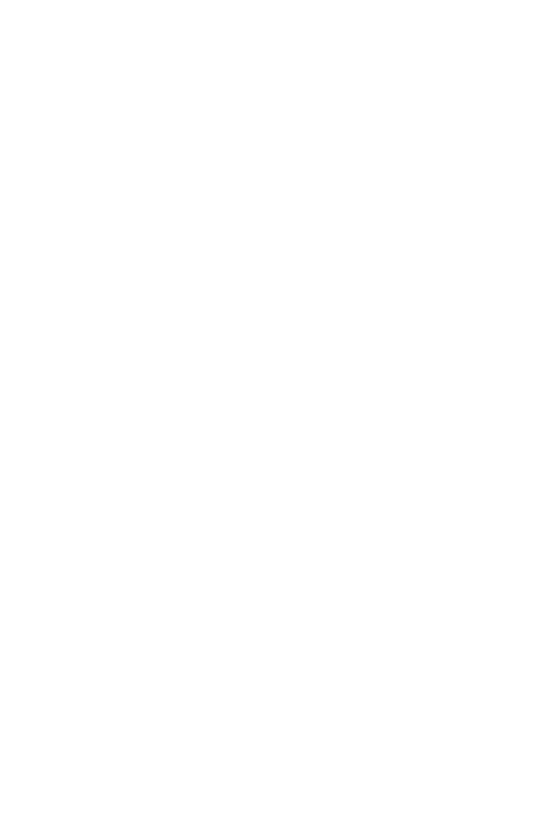

$$
\text { . }
$$

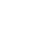
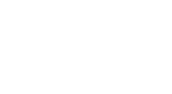

.

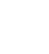

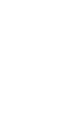




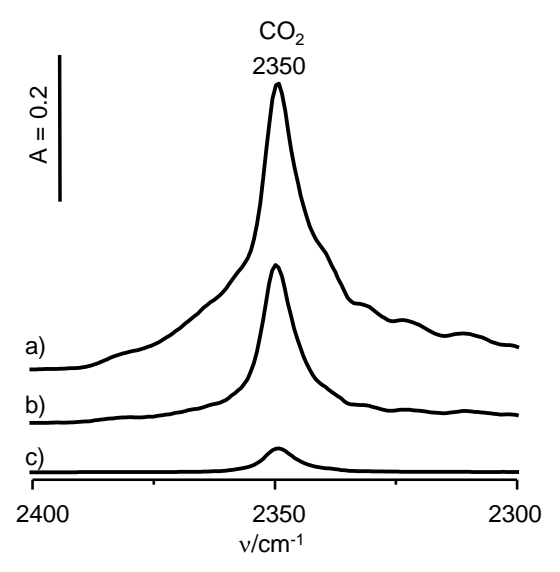

Figure 6

Figure

$\sum_{-10}$

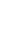

Figure

(n)

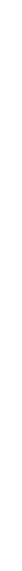




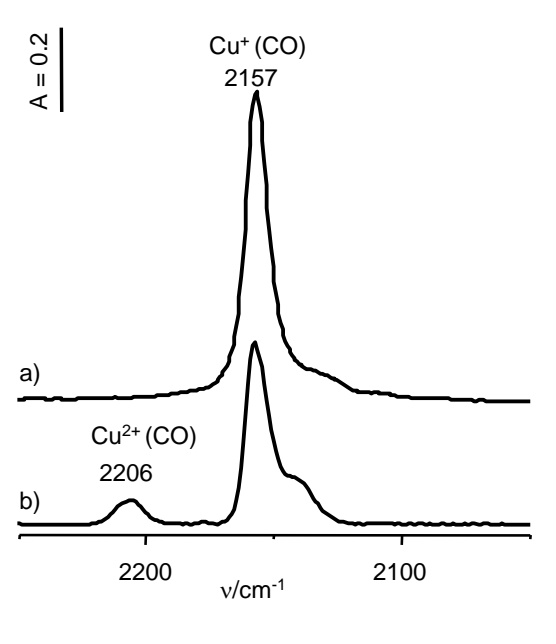

Figure 7

Figure

Figure 7

Figure 7

.

\section{Figu}

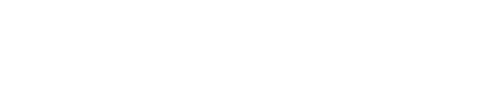

